\title{
Autonomy or SOVEREIgNTy: THE CASE of THE EUropean Union*
}

\author{
Danuta Kabat-Rudnicka \\ Cracow University of Economics, Poland \\ kabatd@uek.krakow.pl
}

KABAT-RUDNICKA, Danuta. Autonomy or Sovereignty: the Case of the European Union. International and Comparative Law Review, 2020, vol. 20, no. 2, pp. 73-92. DOI: $10.2478 /$ iclr-2020-0018

\begin{abstract}
Summary: Sovereignty is a key concept in international law and international relations. First defined and discussed by Jean Bodin, sovereignty is considered to be an inherent attribute of any state. However, the changes that international society has undergone since the Treaty of Westphalia, including the emergence of different state and non-state actors vying for power and authority, have called into question the position of the state as the main actor in the modern world. This in turn has given rise to the following questions: how should the very concept of sovereignty be understood today? Given the growing importance of international organizations and regional integrational arrangements can the concept of sovereignty be extended to cover entities other than states; and in case of the European Union, what makes us think in terms of sovereignty rather than autonomy? This analysis is an attempt to apply the concept of sovereignty to contemporary international organizations. The main thesis is as follows: in the case of international organizations, especially a new type of organization, it is also legitimate to consider a narrative in terms of sovereignty, not just autonomy. The example studied here is the European Union as an international organization-cum-regional integrational arrangement.
\end{abstract}

Keywords: autonomy, sovereignty, international organizations, regional integrational arrangements, European Union.

\section{Introductory remarks}

Sovereignty is a key concept in international law and international relations. First defined and discussed by Jean Bodin, it is seen as an inherent attribute of any state in its internal and external relations. The changes that international society have undergone since the Treaty of Westphalia, especially in terms of the trend towards interdependence and globalization in the 20th and 21st centuries, have called into question the position of the state as the main, if not the only salient power in the world. And nowadays, its status is being further undermined by the emergence of new, often competing non-state actors on the international

* This study is part of considerations on sovereignty of international organizations from the perspective of public international law, see KABAT-RUDNICKA, Danuta, KUŹNIAK, Brygida. Ponadnarodowa organizacja międzynarodowa a kwestia suwerenności - studium międzynarodowoprawne, Przegląd Europejski, 2021. 
scene, which is forcing us into a rethink of the very notion of sovereignty. One new theory being discussed in the context of international organizations, especially those of a supranational character such as the European Union (EU), is that of shared and pooled sovereignty. In turn, the experience of Brexit and similar developments have shown that sovereignty is not simply and exclusively a subject of academic debate. It is a vital issue of state policy. From the viewpoint of the national interest and its manifestation in the state's external relations sovereignty is a value in itself. Bearing in mind the growing importance of international organizations and regional integrational arrangements, it seems legitimate to ask ourselves whether the very concept of sovereignty should first and foremost be associated with a state (as is traditionally the case), or whether it can just as well be applied to non-state entities?

What actually is sovereignty today and how should it be understood? Can sovereignty, which is an integral feature of a state, serve as a useful tool when analysing non-state entities such as contemporary international organizations? And in the case of supranational organizations, of which the EU is the best example, should we think in terms of sovereignty rather than simply autonomy? These are the questions that arise when considering the activities of present-day actors in the international arena.

The present analysis is an attempt to discuss sovereignty as an integral feature of the state to modern-day international organizations. Arguments in support of the thesis that sovereignty is nowadays also becoming an attribute of international organizations will be presented along with a discussion of the relevant literature and case law. The example studied here is the EU - an international organization-cum-integrational arrangement. The discussion will be conducted on the basis of a dogmatic method, a case study and a comparative legal analysis.

According to the traditional understanding of the term, sovereignty is undoubtedly a central component of any state. However, we can also look at sovereignty in a different way and try to tailor it to non-state entities. After all, we speak of the sovereignty of a people, and even of the sovereignty of an individual. Thus, it would appear justifiable to go beyond a state-centric approach towards one that exceeds accepted research frameworks and recognized definitions.

\section{The state of research}

The term 'sovereignty' itself comes from the Latin word superaneus, which means 'the highest'. The original theory of sovereignty was devised by the French philosopher Jean Bodin who considered it to be a unique quality of the state, which itself personified the supreme power when enacting, applying and maintaining law. ${ }^{1}$ The English philosopher Thomas Hobbes added his own twist to the

1 ZETTERQUIST, Ola. Out with the New, in with the Old - Neo-Roman Constitutional Thought and the Enigma of Constitutional Pluralism in the EU. In AVBELJ, Matej, 
concept, arguing that sovereignty was exercised by an artificial person (a state) with supreme power to 'make and abrogate laws, to determine war and peace, to know and judge of all controversies ... to elect all magistrates, ministers and counselors.' ${ }^{2}$ Nowadays sovereignty is a fairly well-researched topic, one that has been explored primarily by lawyers and political scientists.

According to Roman Kwiecień, sovereignty in international law means that a state is not legally subordinate to other entities. It can shape its own legal landscape and define the forms in which it performs its functions. ${ }^{3}$ State sovereignty manifests itself in an autonomous legal order, that is one which is not part of another legal order. ${ }^{4}$ What is more, sovereignty is not a legal norm but rather a basic idea underpinning international law, according to which the international community is based on mutual relations between entities independent of each other. ${ }^{5}$ Sovereignty also implies the ability of a territorial entity to perform state functions as well as functions in relation to other (external) entities. ${ }^{6}$

Matthew S. Weinert offers a slightly different perspective. Rather than interpreting sovereignty as the ultimate and absolute form of power exercised in a political community, which in turn makes us think in terms of territorially defined entities, he suggests instead treating it in terms of the ultimate and absolute power of a political community, in other words shifting our focus to those activities that sustain and develop a political community. ${ }^{7}$ And given that many actors have contributed to the rules that govern state practices, this allows us to view sovereignty as a wider social process. According to this approach, the essence of sovereignty is not determined by individual states, but rather by the wider communities within which states reside, and when discourse is shifted from the highest authority of an entity to the highest authority of welfare of a political community understood as a broad set of human values, sovereignty becomes located in a multi-layered, global, political and legal order, which connects sovereignty with the activities of non-state actors. ${ }^{8}$

In turn, Jiří Přibáň suggests we see sovereignty as a network of dynamic procedures and activities performed in different social contexts and not necessarily

KOMÁREK, Jan (eds). Constitutional Pluralism in the European Union and Beyond. Oxford: Hart Publishing, 2012, p. 215.

2 Ibid.

3 KWIECIEŃ, Roman. Interesy indywidualne państw a interesy wspólnotowe $w$ prawie społeczności międzynarodowej. O znaczeniu liberalizmu i komunitaryzmu dla teorii prawa międzynarodowego. Lublin: UMCS, 2015, pp. 34-35 and 41.

4 Ibid. p. 42.

5 Ibid. p. 87.

6 KWIECIEŃ, Roman. Państwo i jego suwerenność a prawo międzynarodowe jako system prawa. In KWIECIEŃ, Roman (ed). Państwo a prawo międzynarodowe jako system prawa. Lublin: UMCS, 2015, p. 41.

7 WEINERT, Matthew S. Democratic Sovereignty. Authority, legitimacy, and state in a globalizing age. New York: UCL Press, 2007, p. 5.

8 Ibid. p. 73. 
as a set of institutions and norms. ${ }^{9}$ Moreover, since sovereignty in the traditional sense is exercised within certain territorial boundaries, it can therefore be reasonably argued that territory overlaps with sovereignty. ${ }^{10}$ Besides, it is no coincidence that we speak of state sovereignty, as sovereignty and states are closely linked to one another.

As can be seen from above, the concept of sovereignty is applied in many different ways. We can also speak of political and legal sovereignty as well as of internal and external sovereignty. In political terms sovereignty is territorially defined and consists in the exercise of control over individuals (society). It is not limited by any other power of higher or equal rank; and in legal terms sovereignty is defined in relation to legal norms. In other words, those who apply those norms follow and recognise them as valid and superior, and thus the institutions that issue these norms are regarded as sovereign. ${ }^{11}$ External sovereignty means that foreign laws are only applicable in a legal system on the basis of that system's own laws, a condition which makes it independent of other legal systems; internal sovereignty, in turn, corresponds to legal sovereignty and the emphasis is on which institutions exercise supreme authority in a legal system. As such, sovereignty may be located in various institutions that derive their authority from the constitution. ${ }^{12}$

On the other hand, Stephen Krasner evokes such concepts as international legal sovereignty and Westphalian sovereignty, both of which involve authority and legitimacy. In the former case sovereignty rests on the rule of recognition while in the latter it requires the exclusion of external actors from a given territory. Two other forms of sovereignty classified by Krasner are (i) domestic sovereignty, consisting in the elements of authority and control, depending on which authority structures are recognized and how effective their control is, and (ii) interdependence sovereignty, the essence of which is control, i.e. the capacity of a state to regulate movements across its borders. ${ }^{13}$ The attributes of sovereignty

9 PŘIBÁŇ, Jiří. Sovereignty in Post-Sovereign Society. A Systems Theory of European Constitutionalism. London and New York: Routledge, 2015, p. 10.

10 BARENTS, René. The Autonomy of Community Law. The Hague: Kluwer Law International, 2004, pp. 81-82 where we can read '[o]ne of the essential elements of sovereignty is that it is to be exercised within territorial limits, and that ... the territory is coterminous with the sovereignty ... [t] herefore, sovereignty in the modern (constitutional) form is essentially a geographical partitioning of the law.'

11 Sovereignty relates to legal authority, the power to legislate, to oversee the limits of power vested in decision-makers, and ultimately the power to decide who has the authority to legislate, see DYEVRE, Arthur. European Integration and National Courts: Defending Sovereignty under Institutional Constraints? European Constitutional Law Review, 2013, vol. 9, no. 1, p. 149.

12 See Zetterquist (note 1) 216-217.

13 KRASNER, Stephen D. Sovereignty: organized hypocrisy. Princeton, NJ: Princeton University Press, 1999, pp. 4 and 10. 
include territory, autonomy, recognition, and control, ${ }^{14}$ whereby territory (and autonomy) corresponds to Westphalian sovereignty, autonomy (and control) to domestic sovereignty, recognition to international sovereignty, and control to interdependence sovereignty. However, more often than not states do not enjoy all the above attributes. On the other hand, Jurgen Brauer and Robert Haywood list such attributes of (state) sovereignty as legitimate authority (among other things, by means of recognition), supremacy, and territory. ${ }^{15}$

The very concept of sovereignty is primarily associated with the state, even if we do not directly refer to the state as such but rather to a political community. What is more, sovereignty is first and foremost about locating a final authority within the political and legal order.

\section{The European Union as a new subject of international law}

Due to its supranational character, the EU is a new type of international organization. It is based on treaties of international law the parties to which, i.e. the high contracting parties, are Member States. These treaties differ from classical international agreements, for their provisions are binding not only on states but also on citizens. What is more, EU law takes precedence over Member States' laws. As a consequence, it constitutes a new and autonomous legal order in international law. The EU is also a subject of law (a legal entity), for since the entering into force of the Treaty of Lisbon (2009) it has enjoyed legal personality.

There are many arguments in favour of viewing the EU as an international organization. The legal foundations of the EU are treaties of international law the parties to which are its Member States (high contracting parties). And while it is up to the EU to approve the accession of new states, any agreement setting out the conditions and resulting adjustments to the treaties is concluded between Member States and the candidate country, and is only then ratified according to national constitutional requirements. And while it is the EU which decides whether to suspend certain membership rights, including voting rights in the Council, it is the Member States that make sovereign decisions on whether to leave the EU (like the UK did on 31 January 2020) or to exercise the right to optout and thus not participate in certain joint activities. In such an understanding of the Union, the highest-ranking body is the European Council, which not only defines directions and political priorities, but, most importantly, also represents the interests of Member States. Other elements of intergovernmental cooperation include a rotating presidency, the principle of conferral, which clearly defines the limits of the Union's competences, as well as changing borders - a characteristic feature of an international organization rather than of a state structure.

14 Ibid. p. 220.

15 BRAUER, Jurgen, HAYWOOD, Robert. Non-state Sovereign Entrepreneurs and Non-territorial Sovereign Organizations. UNU-WIDER Working Paper, 2010, no. 9, p. 4. 
In turn, the EU may be regarded as a political entity and an international institution that transcends the format of a classical international organization, since it is - in the eyes of some - a quasi-state structure. The EU enjoys legal personality and legal capacity, which means that it can be the subject of rights and obligations; it maintains relations with third countries and enjoys privileges and immunities within the territories of its Member States; it also has institutions that perform legislative, executive and judicial functions and disposes of its own resources. Citizens enjoy dual citizenship, i.e. citizenship of both a Member State and the EU. They also enjoy the right to move to, and reside in, the territories of other Member States, the right to vote for, and stand as candidates in elections to both the European Parliament (EP) and municipal bodies, the right to diplomatic and consular protection from each Member State in the territory of a third country, the right to submit petitions to the EP, to address the Ombudsman, EU institutions and advisory bodies, access the documents of EU institutions, bodies, offices and agencies, as well as the right to personal data protection and to launch citizens' legislative initiatives. Furthermore, the EU recognizes the rights, freedoms and principles enshrined in the Charter of Fundamental Rights (CFR) as well as the rights guaranteed by the European Convention on Human Rights (ECHR). The treaties also refer to the principles of representative democracy, direct democracy and participatory democracy as well as to the principle of institutional balance - a concept unknown to classical international organizations. However, what some might call the most telling symbol of 'statehood' was the introduction of a single currency (euro) in the year 2002.

Among other arguments in support of the thesis that the EU is an international organization are the fact that the EU is a new type of complex international entity. Nor can we ignore the view that the EU should be classified as a constitutional order. The EU owes its constitutional character to, among other things, the jurisdiction of the Court of Justice (ECJ/Court) according to which the treaties established a new, special and autonomous legal order which endows institutions with sovereign rights. On the other hand, and notwithstanding what has just been said above, the EU is a legal and a political entity featuring elements of integration and cooperation, centralization and decentralization, community and intergovernmentalism. In other words, it is a multinational federation based on a constitutional pact, which cannot be reduced either to an interstate treaty or to a state constitution. In short, it is a political entity that defies simple classification. ${ }^{16}$

16 And as van Rossem notes: 'according to the ECJ, the EU forms a unified, self-referential legal order, with its own internal claim to validity, which, at a minimum, is no longer part of the mainstream of international law. VAN ROSSEM, Jan W. The Autonomy of EU Law: More is Less? In WESSEL, Ramses A., BLOCKMANS, Steven (eds). Between Autonomy and Dependence. The EU Legal Order under the Influence of International Organisations. The Hague: T.M.C. Asser Press, 2013, p. 19. 
Another equally important fact is that the EU has been endowed with certain powers, both those 'surrendered' by Member States and those that Member States could not 'surrender' for the simple fact that they never possessed them in the first place (e.g. the establishment of a common currency, single market regulations, European citizenship). Accordingly, some national competences have become new, shared and indivisible with a new content, whereas others can be treated as original, since, due to their scope and content, they could never have been the competences of individual states. ${ }^{17}$ And as Roland Bieber points out '[no] o single member state had powers comparable to those vested in the Union. No individual state could, for example, impose fines on companies acting outside its borders. No state could fix a customs tariff to be applied by other states. ${ }^{18}$ Hence, the competences with which the EU is endowed, are greater than the sum of their transferred competences. They are the organisation's own competences, which it possesses as an autonomous legal entity. ${ }^{19}$

\section{The European Union as an autonomous, supranational and 'sovereign' entity}

Law considered in terms of autonomy implies normative independence from other legal systems. The autonomous nature of EU law comes down to the fact that EU law unilaterally defines its scope and legal effects, and its validity and application in national legal orders does not depend on national constitutions or acts of ratification. ${ }^{20}$ And as Koen Lenaerts points out 'the EU is an "autonomous

17 See Barents (note 10) 233 where we read that such competences 'are original in the sense that because of their scope and content they cannot exist at national level, as a result of which these powers cannot be considered to be transferred by the national acts of ratification. These powers are thus independent to the effect that, in the absence of any provisions to the effect, their exercise is not subject to certain unwritten principles or conditions imposed by national constitutional law. Therefore the legal basis of these powers and the procedural and substantive conditions for their exercise are laid down exclusively in the EC Treaty. This viewpoint is echoed by Zetterquist, who writes '[n]o state can on its own grant its citizens the right to freely move and reside within other Member States. Even an agreement between two (or more) states on these matters would leave the rights of the individual as, at best, accessory to those of the state in question. The EU accordingly functions as an important source of genuine rights for individuals within the European territory, rights that could not be achieved by the Member States on their own. What is more, these rights do not only function as a constitutional parameter against one's own state, they are also operative against other states as a matter of right and not as concession, that is, contestable according to the dialogue principle.' See Zetterquist (note 1) 227.

18 BIEBER, Roland. An Association of Sovereign States. European Constitutional Law Review, 2009, vol. 5, no. 3, pp. 397-398.

19 See KRANZ, Jerzy. Pojęcie suwerenności we współczesnym prawie międzynarodowym. Warszawa: Elipsa, 2015, p. 215.

20 See Barents (note 10) 12 where we read that 'Community law determines its own scope (subject-matter, personal scope, geographical scope, temporal scope), its legal effects on situations coming within its scope (validity, application and interpretation) and its relation to other areas of law (national and international law). This means that the normative content of Community 
legal order" whose constitutional features - such as the principle of direct effect, the primacy of EU law, and the protection of fundamental rights - distinguish it from public international law.. ${ }^{21}$

Another term that equally often comes up in the context of the EU, is supranationality.22 As early as 1952 lawyers issued a legal opinion stating that a supranational organization 'is characterized by its independent position vis-à-vis national governments, the direct applicability of its decisions and the exercise of sovereign powers transferred to it by the Member States. ${ }^{23}$ It needs to be said that the exercise of sovereign rights or - as some wish to call it - sovereign powers does not yet mean that we are dealing with a sovereign entity; in other words, an organization can exercise sovereign rights, which, however, does not necessarily (and does not in reality) make it automatically a sovereign entity. And as René Barents rightly observes

the concept of 'sovereign rights' is not identical to sovereignty ... sovereignty relates to the (hypothetical) supreme and therefore unlimited and permanent power of the state or the sovereign. Sovereign rights constitute a concrete application of this factual or fictitious supreme power (by the 'pouvoir constituant') in the form of specific powers conferred on public authorities designed to that effect by or on the basis of the constitution ('pouvoir constitué) ${ }^{24}$

In light of what has been said above, we cannot but only agree that the EU enjoys sovereign rights, which, however, leaves open the question of whether it is a sovereign entity. The definition of sovereignty entails, among other things, that a sovereign entity can perform all functions independently, whether they be

law (i.e. its character as 'law') is independent from any other rule or system of law.'

21 LENAERTS, Koen. The Kadi Saga and the Rule of Law within the EU. SMU Law Review, 2014, vol. 67, no. 4, p. 707; see also GRILLI, Antonio. Aux origines du droit de l'Union Européenne: Ie "ius commune" national dans les conclusions des avocats généraux: Karl Roemer et Maurice Lagrange (1954-1964). Tijdschrift voor Rechtsgeschiedenis, 2008, vol. 76, no. 1-2, p. 157 where we find 'le droit communautaire se conçoit comme une structure juridique complète, autonome et autosuffisante à côté des ordres juridiques nationaux.'

22 The supranationality we speak of in the context of the EU is not irrelevant, for the more supranational elements possessed by the EU, the more it acts as a sovereign power on the international scene. See JESSURUN D'OLIVEIRA, Hans, Ulrich. The EU and Its Monarchies: Influences and Frictions. European Constitutional Law Review, 2012, vol. 8, no. 1, p. 64.

23 Avis sur la participation des observateurs du Conseil de l'Europe à l'Assemblée commune et sur la conclusion d'un accord à cet effet, Strasbourg, 16 December 1952 (opinion by Ophüls, De Rossi, Reuter) after Barents (note 10) 50-51. Even if Member States 'transfer' some competences for their joint exercise, this does not change the fact that they remain sovereign entities. According to R. Kwiecien ' [i]nternational obligations without doubt diminish the scope of exclusive competences of states ... [b] ut it does not mean that contemporary states are less sovereign than, let's say, 50 years ago. We must remember these are still states themselves that increasingly use their power to limit their power.' KWIECIEŃ, Roman. Sir Hersch Lauterpacht's Idea of State Sovereignty - Is It Still Alive? International Community Law Review, 2011, vol. 13, no. 1-2, p. 40.

24 See Barents (note 10) 219. 
internal (regulating all situations (occurrences) in a given territory) or external (entering into relations with other, external entities). The EU exercises sovereign rights in a defined territory (in principle, the territories of Member States coincide with the area in which EU law applies) and regulates matters (situations/occurrences) concerning persons (natural and legal) residing inside and outside the EU. As regards competences, which by definition are circumscribed due to the principle of conferral, the EU has developed a special category comprising parallel and implied competences, that is competences that are not stated expressis verbis in treaties, but which the EU nevertheless exercises within ex ante defined limits.

The competences referred to above make it possible - according to some for the EU (institutions) to go beyond the principle of conferral. ${ }^{25}$ And it was the ECJ, which played (and still does play) a key role here, with its rulings in, inter alia, the AETR case, ${ }^{26}$ the much earlier case of Federation Charbonier (ECSC) ${ }^{27}$ and one case concerning social policy. ${ }^{28}$ In the Federation Charbonier case the question was whether the High Authority (the Commission) had the power to set prices in the exercise of its regulatory power on the market. Despite the fact that the competence in question was not expressly provided for in the treaty, the Court stated that a regulatory competence implied the competence to set prices, since without this authority such regulatory competence would have no practical effect (effet utile). ${ }^{29}$ In turn, in the AETR ruling the Court declared that the Community's competence to regulate matters relating to road transport (internally) implied a parallel external competence. To this end, it referred to the objectives of the treaty and the Community principle (and even obligation) of loyalty (solidarity). ${ }^{30}$

25 See KLABBERS, Jan. An introduction to international institutional law. Second Edition. Cambridge: CUP, 2009, p. 59 et seq.

26 Judgment of the Court of 31 March 1971, Commission of the European Communities $v$ Council of the European Communities, 22-70, ECLI:EU:C:1971:32.

27 Judgment of the Court of 29 November 1956, Fédération Charbonnière de Belgique v High Authority of the European Coal and Steel Community, 8-55, ECLI:EU:C:1956:11.

28 Judgment of the Court of 9 July 1987, Federal Republic of Germany and others $v$ Commission of the European Communities, 281, 283, 284, 285 and 287/85, ECLI:EU:C:1987:351.

29 Judgment of the Court of 29 November 1956, Fédération Charbonnière de Belgique v High Authority of the European Coal and Steel Community, 8-55, ECLI:EU:C:1956:11 where we read 'the rules laid down by an international treaty or a law presuppose the rules without which that treaty or law would have no meaning or could not be reasonably and usefully applied.'

30 Judgment of the Court of 31 March 1971, Commission of the European Communities $v$ Council of the European Communities, 22-70, ECLI:EU:C:1971:32, par 20-22 where we read ' $[\mathrm{u}]$ nder Article 3 (e) ... [u]nder Article 5 ... [i]f these two provisions are read in conjunction, it follows that to the extent to which Community rules are promulgated for the attainment of the objectives of the Treaty, the Member States cannot, outside the framework of the Community institutions, assume obligations which might affect those rules or alter their scope.' 
Finally, there is also the category of inherent competences that allow the EU to perform all the activities that enable it to achieve its set goals, although not due to any specific sources of an organization's (institution's) power, but simply because they are inextricably linked to that organization. And as Jan Klabbers says

Organizations ... once established, would possess inherent powers to perform all those acts which they need to perform to attain their aims, not due to any specific source of organizational power ... but simply because they inhere in organizationhood. As long as acts are not prohibited in the organization's constituent documents, they must be deemed legally valid. ${ }^{31}$

\section{The European Union in the light of Court of Justice case-law}

We are referring, on the one hand, to constitutional courts, which while safeguarding national constitutional orders and the supremacy of national constitutions, establish a barrier against the unauthorized permeation of EU law into national legal orders, and on the other, to the ECJ, which ensures the uniform application of EU law in national legal systems. Hence, in the Internationale Handelsgesellschaft ruling, the ECJ pointed to the supremacy (and not simply the primacy) of EU law, ${ }^{32}$ while in the Kadi case, it stressed the autonomy of Community law (as do Member States with regard to national law), and thereby furnishing constitutional courts with arguments in favour of scrutinizing EU law, at least in terms of respect for fundamental rights. ${ }^{33}$

In September 2008, the ECJ issued its ruling on the Kadi case, which some commentators regard as one of the Court's most important judgments to date regarding the relationship between Community law and international law. ${ }^{34}$ The case concerned the plaintiff's questioning of the European Community's imple-

31 See Klabbers (note 25) 66.

32 In the judgment we read 'the law stemming from the Treaty, an independent source of law, cannot because of its very nature be overridden by rules of national law, however framed, without being deprived of its character as Community law and without the legal basis of the Community itself being called in question. Therefore the validity of a Community measure or its effect within a Member State cannot be affected by allegations that it runs counter to either fundamental rights as formulated by the constitution of that State or the principles of a national constitutional structure.' Judgment of the Court of 17 December 1970, Internationale Handelsgesellschaft mbH v Einfuhr- und Vorratsstelle für Getreide und Futtermittel, 11-70, ECLI:EU:C:1970:114, par 3.

33 Judgment of the Court of First Instance of 21 September 2005, Yassin Abdullah Kadi v Council of the European Union and Commission of the European Communities, T-315/01, ECLI:EU:T:2005:332; Judgment of the Court of 3 September 2008, Yassin Abdullah Kadi and Al Barakaat International Foundation $v$ Council of the European Union and Commission of the European Communities, C-402/05 P and C-415/05 P, ECLI:EU:C:2008:461; Judgment of the Court of 18 July 2013, European Commission and Others $v$ Yassin Abdullah Kadi, C-584/10 P, C-593/10 P and C-595/10 P., ECLI:EU:C:2013:518.

34 DE BÚRCA, Gráinne. The European Court of Justice and the International Legal Order After Kadi. Harvard International Law Journal, 2010, vol. 51, no. 1, p. 1. 
mentation of a resolution of the United Nations Security Council (UNSC) on the grounds that the latter considered him to be involved in terrorism and had ordered the freezing of his assets. This ruling is seen as a departure from the EU's traditional relationship with international law. The case boiled down to a direct confrontation between the international security system, which aspires to universal application and the possession of universal normative force, and the EU system, situated somewhere between an international organization and a constitutional polity. ${ }^{35}$ The Court used this particular moment to convey a clear message regarding the relationship between Community law and international law, and more specifically, the autonomy of the EU legal order. ${ }^{36}$ However, before the case was referred to the ECJ, it was examined by the Court of First Instance, which not only rejected a dualistic understanding of Community law in the international legal order and the subordinate status of the actions of the then European Community in relation to those of the UNSC wherever their competences overlapped, but at the same time granted itself the right to scrutinize a UNSC resolution with regard to its compliance with the peremptory norms of international law. The Kadi ruling presents the then European Community as an organization with subordinate status that at the same time exerts independent control over competences exercised in the name of the international community under the UN Charter. ${ }^{37}$ In turn, the ECJ annulled the Community regulation to the extent that it imposed sanctions on the plaintiff, while at the same time resorting to dualistic arguments and underlining the fact that Community law is distinct and autonomous from other legal systems, in particular from the international legal order, thus giving priority to the fundamental principles of the Community. And as Gráinne de Búrca notes ' $t$ the ECJ's reasoning was robustly dualist, emphasizing repeatedly the separateness and autonomy of the EC from other legal systems and from the international legal order more generally, and the priority to be given to the EC's own fundamental rules. ${ }^{38}$

In its reasons for judgement, the Court referred not only to the transfer or delegation by Member States of competences to the Community (and later to the Union), but also to the Community's (later the EU's) original competences which derive their legitimacy solely from treaties. And so, in its ruling in the Van Gent en Loos case, the ECJ referred to the sovereign rights of the Community (the institutions), while at the same time pointing to the sovereign rights of Member States, and more precisely their limitation. ${ }^{39}$ The Court also referred to

35 Ibid. p. 5 .

36 Ibid.

37 Ibid. p. 22.

38 Ibid. p. 23.

39 Judgment of the Court of 5 February 1963, NV Algemene Transport-en Expeditie Onderneming van Gend \& Loos v Netherlands Inland Revenue Administration, 26-62, ECLI:EU:C:1963:1 where we find 'by the establishment of institutions endowed with sovereign rights' and 'the Community constitutes a new legal order of international law for the benefit of which the states have limited their sovereign rights.' 
the rights conferred by the treaty. ${ }^{40}$ And as René Barents notes ' $[t]$ his distinction between the sovereign rights of the institutions and those of the Member States demonstrates that according to the Court's doctrine the Community powers are characterized by their original nature. ${ }^{41}$ In turn, when analysing the Community's competences, Barents speaks of their unconditional nature, in the sense that subordination to the authority of the then Community (now the EU) prevents legal persons in respect to whom these powers are exercised from undertaking unilateral actions, and in this case these powers can be defined as sovereign. ${ }^{42}$

The so-called Laval quartet, ${ }^{43}$ i.e. Laval and Viking (2007), Rüffert and Luxemburg (2008) together with earlier cases, namely Schmidberger (2003) and Omega (2004), constituted a veritable revolution in terms of the horizontal effects of ECJ jurisprudence. And this should not simply be seen as a judicial revolution that extended the scope of fundamental rights from state-subject relationships to subject-subject relationships, but also, as Johan van der Walt claims 'a veritable judicial-political revolution that effectively transfers sovereignty from the Member States to the Union., ${ }^{44}$ As a result, EU institutions exercise de facto sovereignty which they do not have, whereas Member States enjoy de jure sovereignty which they do not exercise. ${ }^{45}$ The sovereignty of individual states has remained intact; however, it has lost much of its value, and although Member States remain masters of the Community treaties they are not necessarily masters of the law that applies in their territories. ${ }^{46}$ And as Catherine Barnard rightly points out the Court used the single market provisions to reach deep into an area of national law, an area over which the European Union has, in practice, no competence to (re)regulate. ${ }^{47}$ In addition, according to van der Walt

It is for reason of this subversion of the contractual conferral of competences for which the European Treaties provide that the judicial activism of the ECJ in Laval, Viking and Rüffert can be considered to constitute a de facto assumption of sovereignty that has no de jure backing. This is

40 Judgment of the Court of 21 December 1954, French Republic v High Authority of the European Coal and Steel Community, 1-54, ECLI:EU:C:1954:7 where we can read 'a right granted ... by the Treaty.'

41 See Barents (note 10) 234.

42 Ibid. pp. 235-236.

43 The four judgments known as the Laval Quartet, addressed the conflict between, on the one hand, the fundamental economic freedoms of the common market and, on the other, the right to collective action.

44 VAN DER WALT, Johan. The horizontal effect revolution and the question of sovereignty. Berlin: De Gruyter, 2014, p. 9.

45 In a somewhat different context, see van der Walt (note 44).

46 GRIMM, Dieter. Sovereignty: The Origin and Future of a Political and Legal Concept, New York: Columbia University Press, 2015, p. 77.

47 BARNARD, Catherine. A proportionate response to proportionality in the field of collective action. E.L. Rev., 2012, vol. 37, no. 2, p. 135. 
why one can refer in this regard to a quiet revolution of massive proportions that appears to be taking place in Europe today. ${ }^{48}$

In the context of judicial activism, or what is commonly referred to as a judicial competence-competence, attention should be paid to the recent ruling in the Associação Sindical dos Juízes Portuguese case. ${ }^{49}$ According to Piotr Bogdanowicz, this is one of the most important judgments in the history of European integration, as it greatly interferes with the exclusive competences of Member States, as the very fact that cases adjudicated by national courts may have a potential bearing on the interpretation or application of EU law justifies the application of EU law by the ECJ with all its consequences. ${ }^{50}$ As regards the ECJ, by codifying core values (Article 2 TEU) and abolishing the pillar structure, the Lisbon Treaty provided the Court with an additional tool enabling it to broaden the scope of its jurisdiction, ${ }^{51}$ and yet when traditional teleological interpretation techniques are added to this, we can even speak of 'judicial law-making. ${ }^{52}$

\section{Autonomy or sovereignty?}

While the subject literature includes references to the autonomy of EU law and the independence of EU institutions, hardly any mention is made of sovereignty. ${ }^{53}$ Indeed, sovereignty has traditionally been (and still is) defined as a constitutive feature of a state. However, bearing in mind that when it comes to certain contemporary international organizations such issues as the division of powers, the type of political system adopted and even the question of constitutionality are subjects of discussion, we are therefore justified in attempting to apply the concept of sovereignty itself to the EU. After all, such topics as the notion of universal supranational sovereignty regulating the world community

48 See van der Walt (note 44) 359.

49 Judgment of the Court of 27 February 2018, Associação Sindical dos Juizes Portugueses $v$ Tribunal de Contas, C-64/16, ECLI:EU:C:2018:117.

50 BOGDANOWICZ, Piotr. Jak Trybunał Sprawiedliwości „aktywował” art. 19 ust. 1 TUE w kontekście praworządności: uwagi na tle sprawy C-64/16, Associação Sindical dos Juízes Portugueses. In BARCZ, Jan, ZAWIDZKA-ŁOJEK, Anna (eds). Sadowe mechanizmy ochrony praworzadności $w$ Polsce w świetle najnowszego orzecznictwa Trybunału Sprawiedliwości UE. Warszawa: Elipsa, 2018, pp. 70-71. It is worth pointing out that the obligation to ensure judicial independence (Article 19(1) TEU) does not depend on whether or not there is another EU element in a given case determining the scope of the application of EU law, ibid. p. 67.

51 VAN ELSUWEGE, Peter, GREMMELPREZ, Femke. Protecting the Rule of Law in the EU Legal Order: A Constitutional Role for the Court of Justice. European Constitutional Law Review, 2020, vol. 16, no. 1, pp. 17-18.

52 Ibid. p. 21.

53 One of the few studies is a very interesting article by Ondrej Hamulák where he directly addresses the issue of the sovereignty of the EU, see HAMULÁK, Ondrej. Lessons from the "Constitutional Mythology" or How to Reconcile the Concept of State Sovereignty with European Integration. DANUBE: Law and Economics Review, 2015, vol. 6, no. 2, pp. 75-90. 
are also the subject of academic discourse.$^{54}$ Hence, the mere fact that the EU is not a state should not a priori rule out any discussion of this organization in the context of the notion of sovereignty.

The same literature, however, also informs us that autonomy constitutes a hidden claim to sovereignty, ${ }^{55}$ for sovereignty refers to the highest authority. ${ }^{56} \mathrm{We}$ also learn that to be able to speak of sovereignty in such situations, we need to indicate a constitution (or a constitutional act) so that we can determine what (or who) is defined as being sovereign. ${ }^{57}$ As is well known, the EU does not formally have a constitution, which, however, does not prevent its constitutive treaties from being perceived as constitutional acts, all the more so as it is believed that the 'masters of the treaties' are citizens themselves. ${ }^{58}$

The key issue in the case of the EU, a non-state entity is the ECJ's claim that EU law has supreme authority over national law. ${ }^{59}$ As van Rossem notes 'the real question is not if the Union is still autonomous, but how it imposes its autonomy on the international legal order, in particular on normative decisions or founding documents of (other) international organizations. ${ }^{60}$ It should be pointed out that the EU's position as an autonomous, or - as some would say - sovereign entity, is most pronounced in external relations. ${ }^{61}$

54 See TANZI, Attila. Remarks on Sovereignty in the Evolving Constitutional Features of the International Community. International Community Law Review, 2010, vol. 12, no. 2, p. 148 where we read in extenso 'universal supranational sovereignty regulating an inter-individual global society, in a way similar to the exercise of domestic sovereignty through domestic law.'

55 See van Rossem (note 16) 25 where we read 'autonomy is a disguised claim to sovereignty'; similarly WESSEL, Ramses A., BLOCKMANS, Steven. Between Autonomy and Dependence: The EU Legal Order Under the Influence of International Organisations - An Introduction. In WESSEL, Ramses A., BLOCKMANS, Steven (eds). Between Autonomy and Dependence. The EU Legal Order under the Influence of International Organisations. The Hague: T.M.C. Asser Press, 2013, p. 1 where we read '[s] tressing its autonomy was believed to be necessary to establish an independent identity and could perhaps be seen as a disguised claim to sovereignty, something international organizations - unlike states - have to fight for'; see also GEENENS, Raf. Sovereignty as Autonomy. Law and Philosophy, 2017, vol. 36 , no. 5, pp. 495-524.

56 See van Rossem (note 16) 26

57 Ibid.

58 PERNICE, Ingolf. Multilevel Constitutionalism and the Crisis of Democracy in Europe. European Constitutional Law Review, 2015, vol. 11, no. 3, p. 544.

59 See van Rossem (note 16) 26.-27.

60 Ibid. p. 41.

61 See the Kadi ruling; see also CONTARTESE, Cristina. The autonomy of the EU legal order in the ECJ's external relations case law: From the "essential" to the "specific characteristics" of the Union and back again. CMLR, 2017, vol. 54, no. 6, pp. 1627-1671; and also Opinion of the Court of 16 May 2017, Free Trade Agreement between the European Union and the Republic of Singapore, 2/15, ECLI:EU:C:2017:376 where the ECJ found that the EU had exclusive competence over such areas as: transport, labour and environment. 
It is also believed that the very fact that EU law is directly applicable and takes precedence over (is superior to) the legal orders (systems) of its Member States presupposes EU sovereignty, ${ }^{62}$ or at least it constitutes a claim of sovereignty. And as András Jakab notes 'by accepting supremacy and direct effect, a new sovereign was born'.63 What is more, the creation of a new order does not mean simply pooling competences, and this very fact may equally well support the claim that the EU is a 'sovereign' entity. On the other hand, some commentators believe that the Lisbon Treaty did indeed grant the EU a certain degree of competencecompetence, as the EU can decide how to exercise certain competences without the prior consent of the Member States. This is the case with the simplified revision procedure (article 48(7) TUE), where the consent of States as such is not required, with residual competence (article 352 TFUE), which extends the scope of the application of EU law to all policy areas, even those where the EU has no competence, ${ }^{64}$ and with implied powers in external relations (article 3(2) TFUE), which gives the EU the right to establish an external competence by means of a legislative act. $^{65}$

Generally speaking, autonomy refers to situations where a certain group or organ enjoys a competence and can act within certain limits according to its own rules, whereas sovereignty refers to the supreme authority in a territory, which is independent of any other authority. ${ }^{66}$ And according to René Barents, Community law does not allow a Member State to invoke its status as a high contracting party that can unilaterally determine its rights and obligations; it does not permit a Member State to exercise independent control over the validity and application of Community law in its territory and the status of a Member State as a Community subject is rooted solely in Community law. Thus it is that within the Community a Member State is subject of Community law, ergo it is not a sovereign master. ${ }^{67}$ As a result, the autonomy of Community law challenges one of the attributes of a sovereign state, that is control over the law to which the state and subjects (natural and legal persons) residing in its territory are subjects. ${ }^{68}$ This is because the ability to make and decide what the law is is one of the most salient attributes of sovereignty. ${ }^{69}$ This applies as much, or even more so, to EU law.

62 JAKAB, András. Neutralizing the Sovereignty. Question Compromise Strategies in Constitutional Argumentation. European Constitutional Law Review, 2006, vol. 2, no. 3, p. 386.

63 Ibid.

64 LOCK, Tobias. Why the European Union is not a State: Some Critical Remarks. European Constitutional Law Review, 2009, vol. 5, no. 3, pp. 411-412.

65 Ibid. p. 415.

66 See Barents (note 10) 246-247.

67 Ibid. p. 305.

68 Ibid. pp. 310-311 where we read in extenso ' $t$ the theory of the autonomy of Community law thus challenges one of the essential attributes of the sovereign state: the control over the law to which the state and the subjects in its territory are subject.'

69 See BARTELSON, Jens. Sovereignty as Symbolic Form. London and New York: Routledge, 2014, p. 19. 


\section{Concluding remarks}

Advocates of the sovereignty of Member States refer to the source of EU primary law, i.e. law that is adopted by means of the unanimous decisions of the Member States, which remain masters of the treaties and retain competencecompetence; whereas proponents of EU sovereignty refer to the effects of EU law, that is law which takes precedence over national law, even constitutional provisions, as well as to the competence of the ECJ to settle disputes over the division of competences, which gives the Court what is known as judicial competencecompetence. ${ }^{70}$ However, only when these two standpoints are taken together, do we arrive at the full picture. The state-friendly option ignores the fact that under EU competences states cannot legislate and are subject to an external decisionmaking process, and even the fact that they can participate in law-making in the Council does not change this fact as it does not guarantee that their wishes will be taken into account by EU institutions; whereas the EU-friendly option ignores the fact that the EU is not the master of its own legal basis as it has no right to self-determination, ${ }^{71}$ and, what is more, the claim that the ECJ has competence as the final judge in cases involving a conflict of competences is questionable. ${ }^{72}$

On the one hand, following the ECJ's line of reasoning, we inevitably arrive at the conclusion that the EU has established a new, all-encompassing European sovereign. ${ }^{73}$ On the other hand, however, the fact that states 'have lost' their sovereignty does not necessarily mean that this sovereignty has been taken over by a supranational organization that enjoys at most a certain range of sovereign rights. It should be stressed that states are not the only holders of public authority within their territory, they also recognize another, competing power and sovereignty does not mean an unlimited right to self-determination. And as long as a state provides basic, essential and civilizational goods, it deserves credit and enjoys legitimacy. And if it fails to do so subjects may turn to another source of authority.

To what extent is a state sovereign today? Here we are talking not about de jure sovereignty but rather de facto sovereignty, and not simply due to the fact that a state's sovereign rights are limited when it participates in integration processes, but also because it is owned by interest groups (political and economic, national and international, etc.). On the other hand, it is difficult to regard as sovereign a political, economic and a legal entity if it cannot independently determine its

70 See Grimm (note 46) 91.

71 As said, regarding the simplified treaty amendment and 'lacuna-filling' procedures, since these decisions are not taken by the 'masters of the treaties' (states) but by an EU organ (Council), they constitute a self-empowerment of the EU. See GRIMM, Dieter. Defending Sovereign Statehood Against Transforming the Union Into a State. European Constitutional Law Review, 2009, vol. 5, no. 3, p. 369.

72 See Grimm (note 46) p. 91.

73 WIND, Marlene. Sovereignty and European Integration. Towards a Post-Hobbesian Order. New York: Palgrave, 2001, p. 85. 
legal basis, goals, form or competences. However, it cannot be denied that nowadays the EU enjoys more sovereign prerogatives than ever before. Its legal order is not only constitutional but also autonomous, not only internally but also, and above all else, in its external relations. Hence, we cannot but agree with Eva Lohse when she claims the EU possesses sovereignty within the scope of its own rights, for although both the sovereignty and authority to bind Member States stem from treaties established under international law the EU has progressed much further in the sense that compliance with the provisions on fundamental freedoms is required due to a legal bond with the sovereign $\mathrm{EU}$, and not because the state bound itself in relation to the beneficiaries of the freedoms, i.e. the citizens; and whereas a state limits its actions towards the citizens in order not to violate their freedoms, the main guarantor of fundamental freedoms is the EU, which controls entities that might through their actions impede the establishment of a single market. ${ }^{74}$

Whether or not we are dealing with a sovereign entity depends largely on what definition we refer to, but regardless of diverging definitions, sovereignty is first and foremost about the highest (supreme) authority, and since it is an inherent attribute of a state, sovereignty necessarily relates to a territory. Today, in the international arena, there are numerous actors that compete for power and authority. One of them is the EU - a non-state entity, an international organization of a special kind, which, however, performs state-like functions, enacts laws that are binding not only on states but also on citizens and in some instances even enjoys competence-competence; it possesses neither territory, nor the right to self-determination; however, it acts according to its own principles. Although the EU has no territory as such, its law is applicable, supreme, and can have a direct effect within the territories of its Member States; it is not a state but rather a recognised international actor (e.g. it is the European Commission, not the states as such, which takes part in international trade negotiations; and it is also the EU which signs international agreements); and in terms of autonomy and control, it is the EU that regulates all matters (situations/occurrences) regarding persons (natural and legal) residing within and outside the EU, and all this, in principle, within the framework of circumscribed, treaty-based competences.

Any discussion of the location and exercise of sovereignty should take into account the concepts of divided, limited, shared, common, joint, pooled, or cooperative sovereignty. When considering the location of sovereignty, assuming that the EU is a multilevel structure and an international political entity with federal characteristics, the concept of divided or shared sovereignty comes into play. On the other hand, when it comes to the exercise of sovereignty, or rather sovereign rights, which in most cases is done jointly by the EU and Member States, then pooled sovereignty comes into consideration.

74 LOHSE, Eva J. Fundamental Freedoms and Private Actors - towards an 'Indirect Horizontal Effect'. European Public Law, 2007, vol. 13, no. 1, pp. 175-177. 
The EU is not a state; hence, it does not meet the classical requirements (attributes) of sovereignty. However, we can legitimately claim that the EU is sovereign to the extent that its law is applied and valid within its circumscribed competences. So, why not to resort to a definition of sovereignty, which is functional and territorially-free, according to which a sovereign entity is a body politic with legal personality, with the highest (supreme) authority, and which enjoys legitimacy; and as long as it provides essential and civilizational goods (welfare and prosperity), its subjects will remain loyal and obey the law it enacts. And as Jurgen Brauer and Robert Haywood aptly point out, states are, after all, one particular form of social organization, and if civil society organizes itself in alternative, parallel ways, then other modes of sovereign governance can evolve. ${ }^{75}$

\section{List of references}

Avis sur la participation des observateurs du Conseil de l'Europe à l'Assemblée commune et sur la conclusion d'un accord à cet effet, Strasbourg, 16 December 1952.

BARNARD, Catherine. A proportionate response to proportionality in the field of collective action. E.L. Rev., 2012, vol. 37, no. 2.

BARENTS, René. The Autonomy of Community Law. The Hague: Kluwer Law International, 2004.

BARTELSON, Jens. Sovereignty as Symbolic Form. London and New York: Routledge, 2014.

BIEBER, Roland. An Association of Sovereign States. European Constitutional Law Review, 2009, vol. 5, no. 3.

BOGDANOWICZ, Piotr. Jak Trybunał Sprawiedliwości „aktywował” art. 19 ust. 1 TUE w kontekście praworządności: uwagi na tle sprawy C-64/16, Associação Sindical dos Juízes Portugueses. In BARCZ, Jan, ZAWIDZKA-ŁOJEK, Anna (red). Sadowe mechanizmy ochrony praworządności $w$ Polsce $w$ świetle najnowszego orzecznictwa Trybunału Sprawiedliwości UE. Warszawa: Elipsa, 2018.

BRAUER, Jurgen, HAYWOOD, Robert. Non-state Sovereign Entrepreneurs and Nonterritorial Sovereign Organizations. UNU-WIDER Working Paper, 2010, no. 9.

CONTARTESE, Cristina. The autonomy of the EU legal order in the ECJ's external relations case law: From the "essential" to the "specific characteristics" of the Union and back again. CMLR, 2017, vol. 54, no. 6 .

DE BÚRCA, Gráinne. The European Court of Justice and the International Legal Order After Kadi. Harvard International Law Journal, 2010, vol. 51, no. 1.

DYEVRE, Arthur. European Integration and National Courts: Defending Sovereignty under Institutional Constraints? European Constitutional Law Review, 2013, vol. 9, no. 1.

GEENENS, Raf. Sovereignty as Autonomy. Law and Philosophy, 2017, vol. 36, no. 5.

GRILLI, Antonio. Aux origines du droit de l'Union Européenne: Ie "ius commune" national dans les conclusions des avocats généraux: Karl Roemer et Maurice Lagrange (1954-1964). Tijdschrift voor Rechtsgeschiedenis, 2008, vol. 76, no. 1-2.

GRIMM, Dieter. Defending Sovereign Statehood Against Transforming the Union Into a State. European Constitutional Law Review, 2009, vol. 5, no. 3.

GRIMM, Dieter. Sovereignty: The Origin and Future of a Political and Legal Concept, New York: Columbia University Press, 2015.

75 See Brauer and Haywood (note 15) 16. 
HAMULÁK, Ondrej. Lessons from the "Constitutional Mythology” or How to Reconcile the Concept of State Sovereignty with European Integration. DANUBE: Law and Economics Review, 2015, vol. 6, no. 2.

JAKAB, András. Neutralizing the Sovereignty. Question Compromise Strategies in Constitutional Argumentation. European Constitutional Law Review, 2006, vol. 2, no. 3.

JESSURUN D'OLIVEIRA, Hans Ulrich. The EU and Its Monarchies: Influences and Frictions. European Constitutional Law Review, 2012, vol. 8, no. 1.

Judgment of the Court of 21 December 1954, French Republic v High Authority of the European Coal and Steel Community, 1-54, ECLI:EU:C:1954:7.

Judgment of the Court of 29 November 1956, Fédération Charbonnière de Belgique v High Authority of the European Coal and Steel Community, 8-55, ECLI:EU:C:1956:11.

Judgment of the Court of 5 February 1963, NV Algemene Transport- en Expeditie Onderneming van Gend \& Loos v Netherlands Inland Revenue Administration, 26-62, ECLI:EU:C:1963:1.

Judgment of the Court of 17 December 1970, Internationale Handelsgesellschaft mbH v Einfuhr-und Vorratsstelle für Getreide und Futtermittel, 11-70, ECLI:EU:C:1970:114.

Judgment of the Court of 31 March 1971, Commission of the European Communities $v$ Council of the European Communities, 22-70, ECLI:EU:C:1971:32.

Judgment of the Court of 9 July 1987, Federal Republic of Germany and others $v$ Commission of the European Communities, 281, 283, 284, 285 and 287/85, ECLI:EU:C:1987:351.

Judgment of the Court of First Instance of 21 September 2005, Yassin Abdullah Kadi $v$ Council of the European Union and Commission of the European Communities, T-315/01, ECLI:EU:T:2005:332.

Judgment of the Court of 3 September 2008, Yassin Abdullah Kadi and Al Barakaat International Foundation $v$ Council of the European Union and Commission of the European Communities, C-402/05 P and C-415/05 P, ECLI:EU:C:2008:461.

Judgment of the Court, 18 July 2013, European Commission and Others $v$ Yassin Abdullah Kadi, C-584/10 P, C-593/10 P and C-595/10 P., ECLI:EU:C:2013:518.

Judgment of the Court of 27 February 2018, Associação Sindical dos Juízes Portugueses $v$ Tribunal de Contas, case C-64/16, ECLI:EU:C:2018:117.

KLABBERS, Jan. An introduction to international institutional law. Second Edition. Cambridge: CUP, 2009.

KRANZ, Jerzy. Pojęcie suwerenności we współczesnym prawie międzynarodowym. Warszawa: Elipsa, 2015.

KRASNER, Stephen D. Sovereignty: organized hypocrisy, Princeton, NJ: Princeton University Press, 1999.

KWIECIEŃ, Roman. Sir Hersch Lauterpacht's Idea of State Sovereignty - Is It Still Alive? International Community Law Review, 2011, vol. 13, no. 1-2.

KWIECIEŃ, Roman. Interesy indywidualne państw a interesy wspólnotowe $w$ prawie społeczności międzynarodowej. O znaczeniu liberalizmu i komunitaryzmu dla teorii prawa międzynarodowego. Lublin: UMCS, 2015.

KWIECIEŃ, Roman. Państwo i jego suwerenność a prawo międzynarodowe jako system prawa. In KWIECIEŃ, Roman (ed). Państwo a prawo międzynarodowe jako system prawa. Lublin: UMCS, 2015.

LENAERTS, Koen. The Kadi Saga and the Rule of Law within the EU. SMU Law Review, 2014 , vol. 67 , no. 4 . 
LOCK, Tobias. Why the European Union is not a State: Some Critical Remarks. European Constitutional Law Review, 2009, vol. 5, no. 3.

LOHSE, Eva J. Fundamental Freedoms and Private Actors - towards an 'Indirect Horizontal Effect'. European Public Law, 2007, vol. 13, no 1.

Opinion of the Court of 16 May 2017, Free Trade Agreement between the European Union and the Republic of Singapore, 2/15, ECLI:EU:C:2017:376.

PERNICE, Ingolf. Multilevel Constitutionalism and the Crisis of Democracy in Europe. European Constitutional Law Review, 2015, vol. 11, no. 3.

PŘIBÁŇ Jiří. Sovereignty in Post-Sovereign Society. A Systems Theory of European Constitutionalism. London and New York: Routledge, 2015.

TANZI, Attila. Remarks on Sovereignty in the Evolving Constitutional Features of the International Community. International Community Law Review, 2010, vol. 12, no. 2.

VAN DER WALT, Johan. The horizontal effect revolution and the question of sovereignty. Berlin: De Gruyter, 2014.

VAN ELSUWEGE, Peter, GREMMELPREZ, Femke. Protecting the Rule of Law in the EU Legal Order: A Constitutional Role for the Court of Justice. European Constitutional Law Review, 2020, vol. 16, no. 1.

VAN ROSSEM, Jan, W. The Autonomy of EU Law: More is Less? In WESSEL, Ramses A., BLOCKMANS, Steven (eds). Between Autonomy and Dependence. The EU Legal Order under the Influence of International Organisations. The Hague: T.M.C. Asser Press, 2013.

WEINERT, Matthew S. Democratic Sovereignty. Authority, legitimacy, and state in a globalizing age. New York: UCL Press, 2007.

WESSEL, Ramses A., BLOCKMANS, Steven. Between Autonomy and Dependence: The EU Legal Order Under the Influence of International Organisations - An Introduction. In WESSEL, Ramses A., BLOCKMANS, Steven (eds). Between Autonomy and Dependence. The EU Legal Order under the Influence of International Organisations. The Hague: T.M.C. Asser Press, 2013.

WIND, Marlene. Sovereignty and European Integration. Towards a Post-Hobbesian Order. New York: Palgrave, 2001.

ZETTERQUIST, Ola. Out with the New, in with the Old - Neo-Roman Constitutional Thought and the Enigma of Constitutional Pluralism in the EU. In AVBELJ, Matej, KOMÁREK, Jan (eds). Constitutional Pluralism in the European Union and Beyond. Oxford: Hart Publishing, 2012. 